University of Nebraska - Lincoln

DigitalCommons@University of Nebraska - Lincoln

Faculty Publications in the Biological Sciences

Papers in the Biological Sciences

1993

\title{
Meristic and Organogenetic Variation in Ruppia occidentalis and R. maritima
}

Robert B. Kaul

University of Nebraska-Lincoln

Follow this and additional works at: https://digitalcommons.unl.edu/bioscifacpub

Part of the Biology Commons, and the Botany Commons

Kaul, Robert B., "Meristic and Organogenetic Variation in Ruppia occidentalis and R. maritima" (1993). Faculty Publications in the Biological Sciences. 854.

https://digitalcommons.unl.edu/bioscifacpub/854

This Article is brought to you for free and open access by the Papers in the Biological Sciences at DigitalCommons@University of Nebraska - Lincoln. It has been accepted for inclusion in Faculty Publications in the Biological Sciences by an authorized administrator of DigitalCommons@University of Nebraska - Lincoln. 


\title{
MERISTIC AND ORGANOGENETIC VARIATION IN RUPPIA OCCIDENTALIS AND R. MARITIMA
}

\author{
ROBERT B. KAUL ${ }^{1}$ \\ School of Biological Sciences, University of Nebraska, Lincoln, Nebraska 68588-0118
}

\begin{abstract}
Floral meristic and organogenetic variation was sampled in Ruppia occidentalis from an alkaline lake of the Nebraska Sandhills and in Ruppia maritima var. rostrata from a saline, non-Sandhills lake nearby. The androecium is meristically stable, always having two stamens, but the gynoecium is not. Seventytwo percent of the flowers of $R$. maritima had four carpels and the others had three, and in $80 \%$ of inflorescences the two flowers had the same number. In about one-third of inflorescences having dissimilar carpel numbers, the four-carpellate flower was uppermost. The number of carpels in each flower of $R$. occidentalis ranged from four to nine, averaging six, and in $57 \%$ of inflorescences both flowers had the same number; of those that did not, most had more in the lower than upper flower. Twenty-five percent of the flowers had four carpels, $8 \%$ had five, $35 \%$ had six, $15 \%$ had seven, $14 \%$ had eight, and $3 \%$ had nine. Ordered, dimerous, decussate organogenesis through the first four carpels followed the same pattern in both species, but carpels beyond four were alternate with the first four and the decussate pattern was broken. The stomatiferous dorsal lobe of each carpel produced persistent gas bubbles that probably aid flotation of the inflorescence and might function in trapping pollen as well. Only ephydrophilous pollination was observed in both species.
\end{abstract}

\section{Introduction}

While all species of Ruppia have just two flowers in each inflorescence and two stamens in each flower, there is gynoecial meristic variation within and among species and even between flowers in the same inflorescence. A tetramerous gynoecium is common in the cosmopolitan Ruppia maritima L., but dimery, trimery, and pentamery are known (Posluszny and Sattler 1974b; Jacobs and Brock 1982). Ruppia tuberosa Davis and Tomlinson, Ruppia polycarpa Mason, and Ruppia megacarpa Mason in Australia have two to 19 , four to 16 , and two to seven carpels in each flower, respectively (Brock 1982; Jacobs and Brock 1982). In New Zealand, $R$. polycarpa has two to 16 carpels and $R$. megacarpa usually has four, but the upper flower in its inflorescence sometimes has five or six (Mason 1967; Jacobs and Brock 1982).

Ruppia is often given its own family, Ruppiaceae, or is placed with Potamogeton and Groenlandia in Potamogetonaceae. Recent classifications put it in monocotyledon subclass Alismatidae (Cronquist 1981) or superorder Alismatiflorae (Dahlgren and Rasmussen 1983). Cladistic analysis of the Alismatiflorae by Dahlgren and Rasmussen (1983) showed Potamogetonaceae (including Ruppia) and the marine families Posidoniaceae and Zosteraceae to be synapomorphic and strongly derived. Those authors urged caution in interpreting the cladogram because of convergent evolution. The relatively simple floral morphology of Ruppia, like that of

${ }^{1}$ Reprints available from the author.

Manuscript received January 1993; revised manuscript received April 1993. so many other hydrophilous aquatic plants, probably belies its ancestral complexity, but the Alismatiflorae have a mosaic of ancestral and derived character states, and thus a clear phylogeny of Ruppia and its close relatives is not yet available. Dahlgren and Rasmussen (1983) regarded as plesiomorphic in the monocotyledons the perfect tricarpellate tepal-bearing flower having six stamens in two whorls of three.

The homology of the flower of Ruppia and its tepals, apparent outgrowths of its stamen connectives, have been debated; the various interpretations were reviewed by Singh (1965), Burger (1977), and Posluszny and Sattler (1974b). Less attention has been given to the nature of the gynoecium, and here I present observations on gynoecial meristic variation and floral and fruit organogenesis and function in two species, including a variety of the North American interior, concentrating on aspects not published elsewhere for Ruppia.

Floral anatomy is known for Ruppia from the Mediterranean coast of France (Roze 1894), from Minnesota (Singh 1965) and coastal Connecticut (Graves 1908), and from the interior of Argentina (Gamerro 1968). Some aspects of floral development of $R$. maritima are published for specimens from coastal waters in France (Roze 1894) and Connecticut (Graves 1908) and, in detail, from New Brunswick, Canada (Posluszny and Sattler $1974 b$ ), but none is published from interior waters or for other species.

\section{Material and methods}

I collected Ruppia occidentalis $\mathrm{S}$. Watson from Big Alkali Lake in Cherry County, Nebraska, between high dunes of the Sandhills. The lake and others nearby have growing-season $\mathrm{pH}$ 9-10.3, 
total alkalinity (carbonates) of $700-34,000 \mathrm{mg} /$ $\mathrm{L}$, and $\mathrm{Na}^{+}+\mathrm{K}^{+}$of $700-2,200 \mathrm{mg} / \mathrm{L}$. I gathered Ruppia maritima L. var. rostrata Agardh from saline Oak Lake in Lancaster County, Nebraska, outside the Sandhills; the lake has a mud bottom, growing-season $\mathrm{pH}>9.5$, fewer carbonates (ca. $265 \mathrm{mg} / \mathrm{L}$ ), and $\mathrm{Na}^{+}+\mathrm{K}^{+}$of ca. $1,100 \mathrm{mg} / \mathrm{L}$ (Kaul 1992). I grew transplanted flowering plants of both species in tapwater in the laboratory under fluorescent lights where, for $3 \mathrm{wk}$, they produced foliage and flowers that liberated pollen.

The species reported on are readily separable using floral and vegetative characters (Kaul 1992) and are ecologically segregated, as noted above. Ruppia occidentalis in the Sandhills has stamens about $1 \mathrm{~mm}$ wide; four to nine carpels; fruiting peduncles long and strongly coiled; fruits $1.8-3$ $\mathrm{mm} \times 1.6-2.4 \mathrm{~mm}$; and two prominent elliptic white soft spots on the hard black endocarp. In my specimens of $R$. maritima, the stamens are ca. $0.6 \mathrm{~mm}$ wide; the carpels number three or four; the short fruiting peduncles are uncoiled; the fruits are $1.2-1.9 \mathrm{~mm} \times 1-1.3 \mathrm{~mm}$; and the endocarp spots are nearly circular. The leaves of $R$. maritima and $R$. occidentalis are, respectively, acute and obtuse, denticulate and entire, flattened and terete, and unspotted and red-spotted; and the fruiting peduncles of the two species are straight and coiled, respectively.

Specimens were dissected and examined living and after fixation in 70\% formalin-propionic acid-ethanol (FPA). Specimens for scanning electron microscopy were dehydrated in a series to absolute ethanol, critical-point dried, and sputter-coated for $5 \mathrm{~min}$ with gold-palladium. Those for light microscopy were stained with fuchsin and sectioned in paraffin-plastic.

The flowers are described as seen in polar view while attached on the sides of the inflorescence rachis, its distal end uppermost. Thus, each flower has an "upper" and "lower" half, and its appendages occur in positions easily described using hours of the clockface.

\section{Observations}

\section{ORGANOGRAPHY}

In both species, the vegetative phyllotaxy is distichous and the shoot system becomes sympodial when the first inflorescence primordium appears. A renewal shoot arises immediately below each inflorescence and eventually terminates in an inflorescence. Each inflorescence has two flowers, neither subtended by a bract, one $180^{\circ}$ from and slightly above the other and developmentally lagging it (figs. $1 C, F ; 2 C ; 3 C$ ). Both flowers are in the median plane of the two subopposite leaves whose sheaths enclose the developing inflorescence, thus continuing the distichy of the vegetative stem into the inflorescence.
Table 1

CARPEL NUMBERS IN FLOWERS AND INFLORESCENCES

\begin{tabular}{|c|c|c|c|c|c|c|}
\hline & \multicolumn{3}{|c|}{$\begin{array}{c}\text { Ruppia maritima var. } \\
\text { rostrata }\end{array}$} & \multicolumn{3}{|c|}{ Ruppia occidentalis } \\
\hline & \multicolumn{2}{|c|}{$\begin{array}{c}\text { Carpels per } \\
\text { flower in } \\
\text { inflorescences }\end{array}$} & \multirow{2}{*}{$\begin{array}{l}\text { No. of } \\
\text { inflo- } \\
\text { res- } \\
\text { cences } \\
(N \\
=96)\end{array}$} & \multicolumn{2}{|c|}{$\begin{array}{l}\text { Carpels per } \\
\text { flower in } \\
\text { inflorescences }\end{array}$} & \multirow{2}{*}{$\begin{array}{l}\text { No. of } \\
\text { inflo- } \\
\text { res- } \\
\text { cences } \\
(N \\
=96)\end{array}$} \\
\hline & $\begin{array}{l}\text { Lower } \\
\text { flower }\end{array}$ & $\begin{array}{l}\text { Upper } \\
\text { flower }\end{array}$ & & $\begin{array}{l}\text { Lower } \\
\text { flower }\end{array}$ & $\begin{array}{l}\text { Upper } \\
\text { flower }\end{array}$ & \\
\hline & 3 & 3 & 17 & 4 & 4 & \\
\hline & 3 & 4 & 6 & 5 & 5 & 6 \\
\hline & 4 & 3 & 13 & 5 & 7 & 3 \\
\hline & 4 & 4 & 60 & 6 & 6 & 17 \\
\hline & & & & 7 & 6 & 19 \\
\hline & & & & 7 & 7 & 3 \\
\hline & & & & 8 & 6 & 14 \\
\hline & & & & 8 & 8 & 4 \\
\hline & & & & 8 & 9 & 3 \\
\hline & & & & 9 & 8 & 2 \\
\hline & & & & 9 & 9 & 1 \\
\hline $\bar{X}$. & 3.76 & 3.69 & & 6.22 & 5.80 & \\
\hline & & 52 & & & .82 & \\
\hline & & .087 & & & .29 & \\
\hline & 1 & & & 1 & & \\
\hline & & IS & & & .025 & \\
\hline Overall $\bar{X}$ & & 72 & & & .95 & \\
\hline$s \ldots \ldots$ & & 45 & & & .46 & \\
\hline$\chi^{2} \ldots \ldots$ & & .02 & & 76 & & \\
\hline df. . . . & 1 & & & & & \\
\hline$P \ldots \ldots$ & & 025 & & & .001 & \\
\hline
\end{tabular}

\section{MERISTIC VARIATION}

The number (two) and position (6 and 12 o'clock) of stamens was unvarying in all specimens of both species I examined, irrespective of the number and position of carpels. Occasional flowers had undehisced anthers that were fullsized but collapsed and empty of pollen (fig. $2 F$ ). In most such specimens, both flowers of the inflorescence had barren anthers, but the carpels were fertile.

There was variation in number of carpels within and between inflorescences (table 1). In my collection, $72 \%$ of the flowers of Ruppia maritima had four carpels (fig. $1 D, E$ ) and all others had three (fig. $1 F$ ). In $80 \%$ of the inflorescences, both flowers had the same number of carpels, and $22 \%$ and $78 \%$ of those flowers had three and four carpels, respectively. In the other $20 \%$ of inflorescences, one flower had four carpels and the other had three, and the four-carpellate flower was uppermost on the rachis in about one-third of them (table 1).

Meristic variation was more complex in flowers of Ruppia occidentalis. The carpel number ranged from four to nine in a flower, averaging six. In $57 \%$ of inflorescences, both flowers had the same number, and of those that did not, most had more in the lower than upper flower 


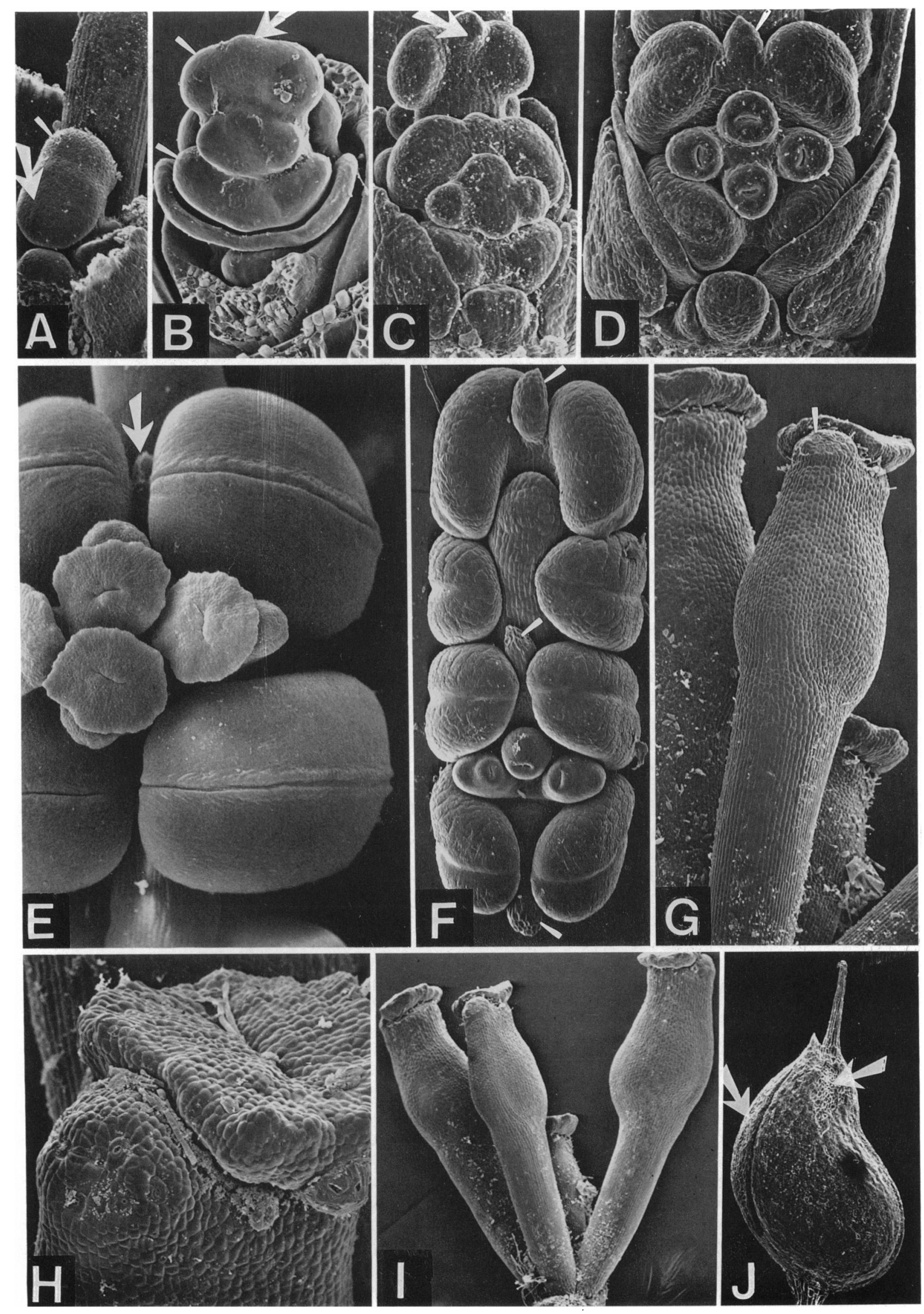


(table 1). Twenty-five percent of the flowers had four carpels, $8 \%$ had five (fig. $2 E$ ), $35 \%$ had six (fig. $2 A, B$ ), 15\% had seven, $14 \%$ had eight (fig. $2 C, D$ ), and $3 \%$ had nine (fig. $2 F$ ). In some fourand nine-carpellate flowers, the fourth and ninth carpels (fig. $2 F$ ) to appear, respectively, were abortive. Some fully formed carpels abort after anthesis, presumably for lack of pollination or from competition among developing fruits (fig. 1I).

Within inflorescences, the average number of carpels is greater in the lower flower of both species, but the difference is statistically significant only for $R$. occidentalis (table 1). In both species, the differences among numbers of carpels in all flowers combined, regardless of their position in the inflorescence, are statistically significant (table 1). Within-inflorescence differences in carpel number do not exceed one carpel between the two flowers of $R$. maritima and two carpels between those of $R$. occidentalis, although differences among all flowers in the latter species are as great as five carpels and as high as 10 carpels among inflorescences (table 1).

\section{ORGANOGENESIS}

Floral organogenesis through the four-carpellate stage is similar in both species (fig. $1 A-E$ ). The primordial inflorescence first appears as a featureless projection, but each flower primordium is soon evident as a large, lateral, flattened lobe, the lower one slightly more advanced than the upper (fig. 1A). In each flower primordium, the lower-stamen primordium is the first externally evident structure, and that of the upper stamen arises next (fig. 1B). A tepal appears as an apparent outgrowth of the connective, first on the primordium of the upper stamen, then on the lower (fig. $1 A, B$ ). At first it is nearly radial, but at maturity it is somewhat dorsiventrally flattened and rather thick and unvascularized; it is often hidden by the mature anthers (fig. $1 E$ ). In
$R$. maritima the tepal is more or less acute at maturity (fig. $1 F$ ), but in $R$. occidentalis it is obtuse (fig. $2 B, E$ ). By anthesis, the wide connective and the sessile thecae nearly encircling the rachis of the inflorescence create the impression of a four-staminate flower (figs. $1 E, F ; 2 B, E, F$ ).

While the stamens are yet immature, the first two carpels appear, often simultaneously but occasionally one slightly preceding the other, in the median transverse plane, i.e., the 3 and $90^{\prime}$ clock sites alternate with the stamens (fig. $1 B, C$ ). They are soon followed by a second pair in the median vertical plane (6 and 12 o'clock), opposite the stamens, the upper carpel often slightly preceding the lower (fig. 1C). The first pair of carpels retains its lead for a short time, but the second pair catches up. Sometimes the fourth carpel, in the 6 o'clock site, does not develop fully and resembles the abortive ninth carpel in figure $2 F$. When a fourth carpel does not appear at all, a three-carpellate flower results, but the space for the fourth carpel remains (fig. $1 F$ ), and the floral phyllotaxis is otherwise as in four-carpellate flowers.

In five- and six-carpellate flowers of $R$. occidentalis, organogenesis is as described above for four-carpellate flowers, but a fifth carpel appears in the 4 o'clock position, alternate with and after carpel primordia of the two pairs already evident (fig. $2 E$ ). A sixth carpel arises after the fifth, in the 8 o'clock position (fig. $2 A, B$ ). I did not find developmental stages of seven-carpellate flowers.

In eight-carpellate flowers of $R$. occidentalis, the first four arise in sequential pairs, as described above for four-carpellate flowers. Then, alternate with the first four carpel primordia, four more appear but not always synchronously (fig. 2C). The upper two, in the 2 and 10 o'clock positions, often slightly precede the lower two in the 4 and 8 o'clock positions. When a ninth carpel is formed, it is often nearly central in the gynoecium and is sometimes fertile and sometimes abortive (fig. $2 F)$.

Fig. 1 Ruppia maritima var. rostrata: SEM micrographs of flowers and fruits. $A-E$, Floral organogenesis of a four-carpellate flower. $A$, Inflorescence primordium with two floral primordia, the lower one (arrow) facing the viewer, the upper one (pointer) facing away. $\times 100 . B$, Flower primordium with upper and lower stamens (pointers) developing thecae, and the connective just beginning to show its apparent outgrowth, the tepal (arrow); the upper stamen arose after the lower and still lags it in size, and the first two carpel primordia have appeared in the transverse plane. $\times 152 . C$. Floral primordia of both flowers on an inflorescence. In the lower flower (facing the viewer) the upper stamen is now somewhat larger than the lower, and the second pair of carpels has appeared in the median vertical plane. The tepal (arrow) shows with the upper stamen of both flowers. $\times$ 131. $D$, Still older primordium of a flower. The thecae of the anthers are now prominent, and the tepal (pointer) is clearly evident with the upper stamen, but that on the lower stamen is not visible here. The four carpels are now about at the same developmental stage. $\times 110$. E, Flower near anthesis. A tepal (arrow) is barely visible with the upper stamen. The flaring stigma and stomatiferous lobe of each carpel are prominent. $\times 60 . F$. Immature inflorescence, the lower flower (facing the viewer) with three carpels. Three tepals (pointers) are prominent, two on the lower flower and one on the upper stamen of the upper flower. $\times 75 . G$, Carpels after pollination, the podogyne (with diatoms) now forming from the carpel base. The stomatiferous lobe (pointer) is evident by the stigma, but there are no stomata elsewhere on the carpel (cf. fig. $1 I$ ). $\times 65$. $H$, Detail of stomatiferous lobe (left) and stigma (right) $\times 165 . I$. Four carpels of one flower after anthesis, three now immature drupelets, the fourth probably not pollinated and not growing further. $\times 29 . J$, Naked endocarp of mature fruit (lustrous black in life), the softer pericarp layers having disintegrated. The prominent stylar beak (top right) is much larger than the tiny beak (top left) that formed in the stomatiferous lobe. The valve (left arrow) will open, hinged at its base, when the seedling emerges. One of the two parenchymatous spots (white in life) is shown (right arrow). $\times 32$. 

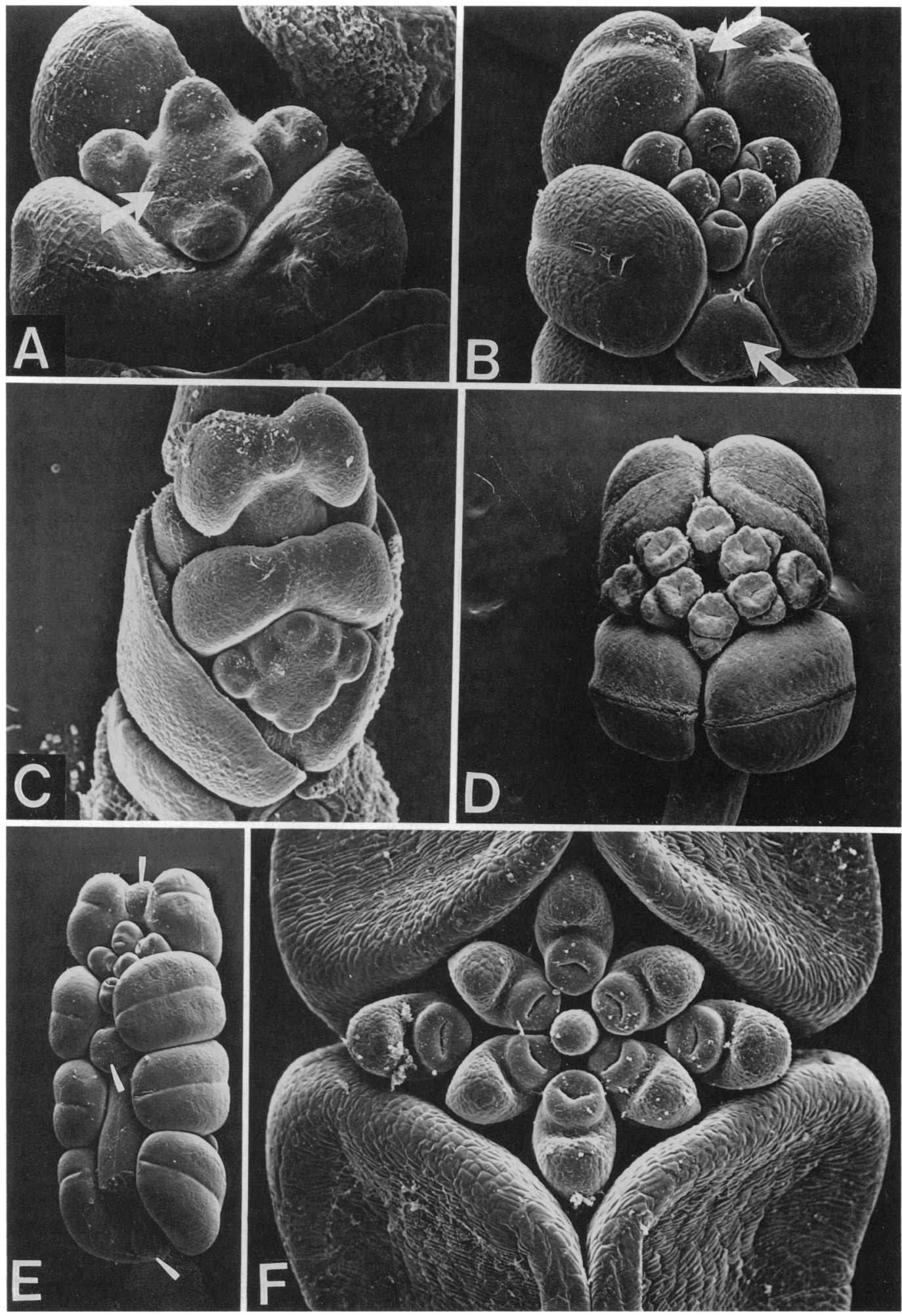

Fig. 2 Ruppia occidentalis floral primordia. $A, B$, Six-carpellate primordia. $A$, Primordium just after appearance of the fifth and sixth carpels in the 4- and 8-o'clock sites, the 8-o'clock carpel (arrow) slightly lagging the 4-o'clock carpel, and both lagging all others. All three pairs of carpels are still at different developmental stages. $\times 130 . B$, Older primordium of six-carpellate flower, the carpels about equally well developed and the adnate tepal (arrows) prominent with each stamen, between the thecae. $\times 81 . C, D$, Eight-carpellate flower. $C$, Inflorescence with two primordia, that of the lower flower facing the viewer and partially concealed. Tepals barely evident. All eight carpel primordia have appeared. $\times 97 . D$, Flower near anthesis, with six carpels in a pseudowhorl and the other two, which arose first, beside it. Anthers nearing dehiscence. $\times 20 . E$, Inflorescence primordium with its upper, five-carpellate flower facing the viewer and its rounded tepals (pointers) evident. $\times 35 . F$, Nine-carpellate flower primordium, the last-formed ninth carpel central and abortive. Anthers barren and collapsed but undehisced. $\times 190$. 

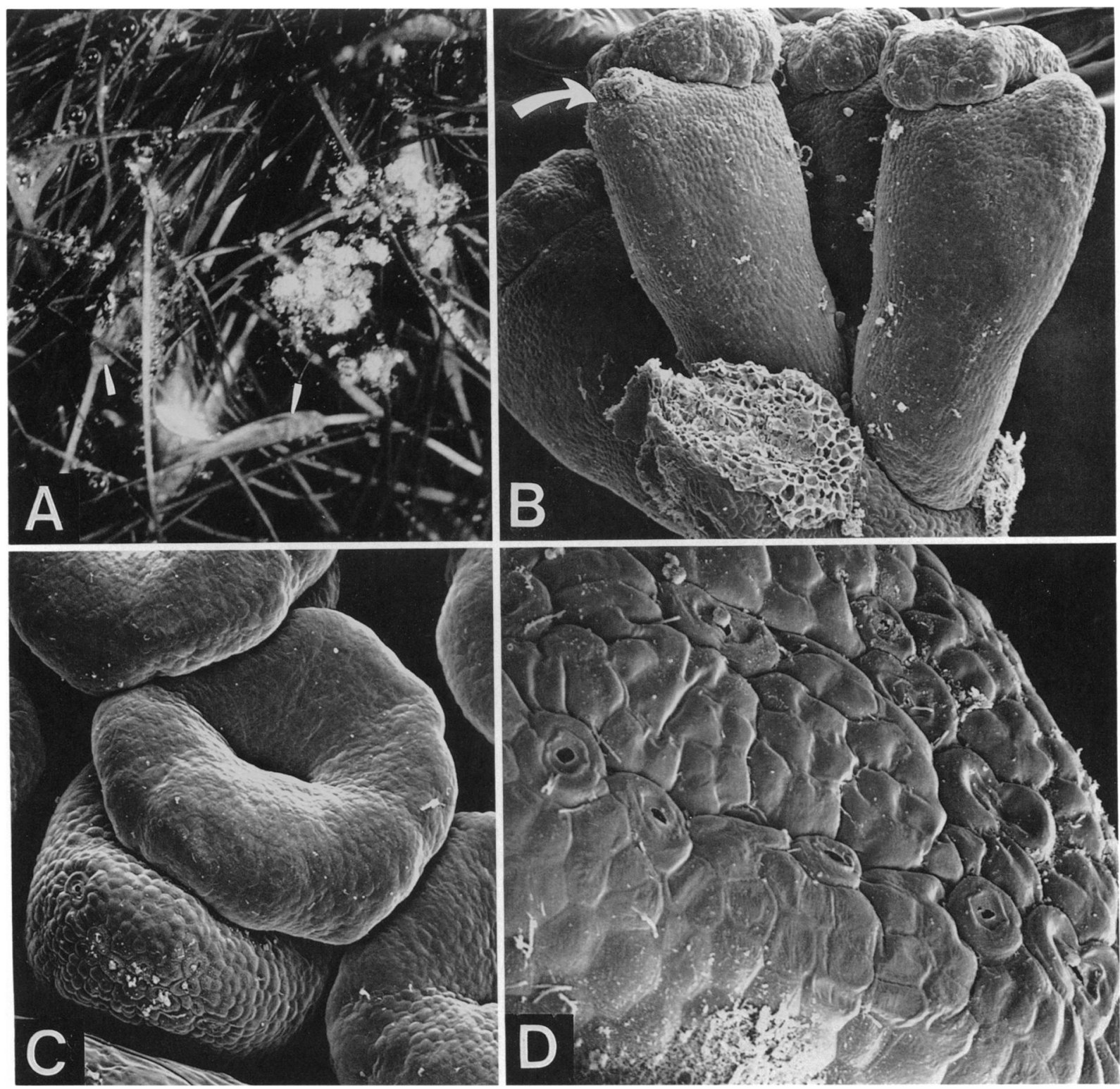

Fig. 3 A, Ruppia maritima var. rostrata seen from above in the wild, at pollination time. Inflorescences are visible floating parallel to and just below the water surface (pointers), and large quantities of floating pollen have been liberated from anthers at the surface. $\times 1 . B-D$, Ruppia occidentalis carpels near anthesis. $B$, Lateral view of four-carpellate flower with anthers and tepals broken away. Stomatiferous lobe (arrow) evident on two carpels, but there are no stomata elsewhere on the carpels. $x$ 70. $C$, Stigma (center) and stomatiferous lobe (lower left) in polar view. $\times 161 . D$, Surface of stomatiferous lobe showing rows of stomata. $\times 635$.

In both species, the dorsal (abaxial) side of the carpel primordium enlarges very early, rendering the young carpel asymmetric (figs. $1 D, F ; 2 B, E$, $F)$. A prominent dorsal lobe forms next to the stigma and equals it in height through anthesis (figs. $1 G-I ; 2 F ; 3 B, C$ ). This lobe has large stomata (figs. $1 G, H ; 3 C, D$ ) and prominent substomatal chambers, but there are none elsewhere on the carpel (figs. $1 G, 3 B$ ). The entire carpel, including the stigma, is green and photosynthetic, and large, persistent bubbles of gas, presumably oxygen, emerge from the stomata while the flowers are floating, after the anthers have broken away. In all carpels, the stylar opening appears as a transverse slit well before the prominent, flaring, peltate stigma forms, and it remains as a slit through anthesis (figs. $1 D-F ; 2 A-F ; 3 C$ ).

\section{POLLINATION AND FRUITING}

The peduncle elongates rapidly as anthesis approaches, bringing the two flowers out of the protecting sheaths and up to the water surface, where the rachis lies parallel to the water surface (fig. $3 A$ ). Pollination is ephydrophilous in both species: the large, elongate, hydrophobic pollen grains float to the stigmas, which are presented at the 
surface, and sometimes the surface is white with pollen (fig. $3 A$ ). In my collection site and in cultivation, the anthers opened only after they reached the water surface, whether or not they were still attached to the flower. After pollination, each inflorescence of $R$. occidentalis is pulled underwater by the strong coiling of the long peduncle, but those of $R$. maritima sink, rather than being pulled, because their shorter peduncles do not coil.

Each pollinated carpel matures underwater into a drupelet, all those in a single flower collectively forming a drupecetum of free carpels. Often one (fig. 1I) or more carpels do not develop into a mature fruit, presumably from lack of pollination or from competition from other carpels. In both species studied, the fruits are elevated from the receptacle on a long stipe, the podogyne, that develops from the base of each carpel (fig. $1 G, H$ ). The pronounced asymmetry of the carpel at anthesis (figs. $1 E ; 2 D ; 3 B, C$ ) decreases, partly because the stomatiferous lobe does not grow and is, in fact, not readily apparent at fruit maturity.

The fleshy pericarp disintegrates while the fruits are attached to the receptacle, as do the outer layers of the podogyne. Thus, the naked black endocarp, adnate to the single seed within, remains attached (fig. $1 J$ ), often until the entire shoot disintegrates.

In both species the hard and very lustrous black endocarp forms as the fruit approaches full size (fig. $1 J$ ). It is less symmetrical than the softer tissues surrounding it, and it reaches into the stylar canal as a sharp beak; a second, much shorter beak forms in the area of the dorsal lobe of the carpel, especially in $R$. maritima (fig. $1 J$ ). Two rather large white spots form subapically, on the flat sides of the endocarp, near the beak (figs. $1 J$, $4 C$ ); they are much softer and more spongy than the other parts of the endocarp, and their tissue extends entirely through it. The endocarp valve (fig. $1 J$ ) remains sealed until the seedling emerges, when it opens basipetally, drawbridge-style.

\section{Discussion}

While there is absolute meristic stability in the androecium and tepals of Ruppia, the gynoecium is meristically unstable but organogenetically ordered, at least through the eighth carpel. The firstformed sets of appendages, including the androecium and the first two pairs of carpels, are dimerous and decussate, although members of the pairs usually arise asynchronously. Furthermore, while the eight- and nine-carpellate gynoecium at maturity appears to have an inner whorl of six carpels, those six do not arise synchronously as one whorl or as two whorls of three as might be expected in a monocotyledonous flower. Instead, they can be interpreted as three sets of two or as one set of two and one of four, producing a pseudowhorl, for which the carpels of the first pair are always outside. In six-carpellate flowers, the pseudowhorl contains the four last-formed carpels and, as in eight-carpellate flowers, the first-formed pair is outside it.

The floral phyllotaxy of Ruppia, with its decussate and dimerous early appendages giving way to nondecussate phyllotaxy in multicarpellate gynoecia, and its unsettled gynoecial merism but fixed androecial dimerism, are departures from the trimerous whorls presumably basic in the monocotyledons (Dahlgren and Rasmussen 1983). In flowers, the relationship of dimery to trimery is close (Endress 1987; Kubitzki 1987), and the latter is likely ancestral to the former. The perianth and androecium precede the gynoecium in the process (Kubitzki 1987), as is evident in Ruppia, where an indication of spiral phyllotaxy is most pronounced in the later-formed carpels. That whorled, spiral, and unordered phyllotaxy can coexist is discussed by Endress (1987), who notes that phyllotactic lability is common in flowers, such as those of Ruppia, with free parts.

The tetramerous gynoecium, common in some species of Ruppia, is uncommon in monocotyledons but occurs in some species of Potamogeton (Potamogetonaceae) and Aspidistra (Liliaceae sensu lato, Convallariaceae), the entire Cyclanthaceae, and scattered elsewhere. While it is uncertain how those gynoecia arose, they probably have a trimerous ancestry (Dahlgren and Rasmussen 1983). The trimerous gynoecium evident in the $28 \%$ of flowers of Ruppia maritima in my sample, however, is secondarily derived from tetramery through failure of a fourth carpel to develop, as evidenced by abortive fourth carpels in some four-carpellate flowers and by the large space left in the fourth-carpel position in three-carpellate flowers. Nevertheless, the stabilized position of the early carpels and the lability of the later carpels indicates that the gynoecium of Ruppia has a polycarpellate, possible spiral ancestry. Furthermore, its foliar distichy continues into the inflorescence and, modified, into its flowers, where the change from distichous leaves and flowers to decussate early floral organs represents internodal compression and the phyllotactic rearrangements that accommodate it. Thus, the arrangement of the paired but not necessarily synchronously arising floral organs does not represent a drastic phyllotactic departure from that produced by the vegetative apex. Furthermore, the two relatively huge anthers, which are much more voluminous than the entire gynoecium at anthesis (fig. $1 E$ ), occupy most of the tiny flower and cannot be accommodated except in a distichous/decussate arrangement, where they are as far apart as possible.

Organogenetic patterns similar to those of Ruppia are shown for closely related Potamogeton by 
Posluszny and Sattler (1973, 1974a) and Charlton and Posluszny (1991). Each tepal of Potamogeton is paired with a stamen, as it is in Ruppia, and when only two are present-uncommon in Potamogeton but always the case in Ruppiathey are the upper and lower median ones in the 6 and 12 o'clock positions in both genera; where there is one in Potamogeton, it is usually the upper one. In tetramerous flowers of Potamogeton, by contrast with Ruppia, the carpels are alternate with the stamens. While tetramery is normal in some species of Potamogeton, there is gynoecial meristic variation in others, sometimes in the absence of androecial variation, as in Ruppia. Extra carpels arise alternately with the first four, but sometimes the arrangement is less regular; fifth and even sixth carpels, for example, often appear in the median plane between the upper or lower two of the first whorl, and gynoecia with even more carpels show an apparently spiral arrangement (Charlton and Posluszny 1991), again a pattern approaching that of Ruppia.

Meristic variation of flowers within inflorescences of four species of Potamogeton showed a general acropetal increase in meristic variability of flowers, often with a general decline in numbers of tepals, stamens, and carpels in the flowers (Charlton and Posluszny 1991). Such variability cannot exist in a two-flowered inflorescence of Ruppia, of course, but it is approached in the aggregate when numerous inflorescences are analyzed: there are slightly fewer carpels, on average, in the upper than lower flower in both species, and the overall differences in carpel numbers per flower are only one in $R$. maritima but up to five in Ruppia occidentalis.

Charlton and Posluszny (1991) concluded that the number of carpel primordia in a flower of Potamogeton probably depends on their size relative to that of the floral apex that bears them, a conclusion that likely applies to Ruppia as well. Yet there is considerable unused floral meristem in Ruppia flowers with three and four carpels (fig. $1 C, F$ ), seemingly enough for another carpel primordium or two. The abortive fourth carpel that sometimes occurs in the 6 o'clock position of some four-carpellate flowers, however, clearly has enough room to develop fully (fig. $1 F$ ).

I agree with Singh (1965) that the flower of Ruppia is best interpreted as a true flower, not a pseudanthium, and that the apparent outgrowth of the stamen is a tepal. Furthermore, the meristic independence of androecium from gynoecium suggests a euanthial, not a pseudanthial, interpretation. The common primordium of tepal and stamen is not unique in epitepalous androecia and indicates evolutionary adnation (see Tucker [1989] for a discussion of common primordia). The lack of vascularization in the tepals is to be expected, considering their tiny size, short life, and aquatic environment. As noted by Singh (1965), the persistence of the tepals after the anthers have broken away shows them to be independent organs.

Gamerro (1968), Verhoeven (1979), Van Vierssen et al. (1982), Cox and Knox (1989), and others reported ephydrophily in various species of Ruppia, including $R$. maritima. For $R$. maritima, Verhoeven (1979) observed underwater pollination in which pollen is released on persistent bubbles from submersed anthers, analogous to the system suggested by Philbrick (1988) for species of Potamogeton pollinated underwater by bubble-borne pollen. My observations confirm ephydrophily for both species in the wild and for $R$. maritima in cultivation as well. I did not observe pollen or pollen-bearing bubbles issuing from submersed anthers. My observations of persisting bubbles arising from the stomata of the carpel lobe suggest them to be traps for floating pollen and/or that they aid flotation of the inflorescence by acting as buoys, as noted by Verhoeven (1979) for Ruppia cirrhosa. Flotation is probably also aided by the spongy tissue in the stomatiferous lobe.

\section{Acknowledgments}

I am grateful to Kit-Wah Lee, who provided valuable assistance at the scanning electron microscope, to Yuen-Po Yang for figure $1 E$, and to Steven Rolfsmeier and David Sutherland for help in the field.

\section{Literature cited}

Brock, M. A. 1982. Biology of the salinity tolerant genus Ruppia L. in saline lakes in South Australia. I. Morphological variation within and between species and ecophysiology. Aquat. Bot. 13:219-248.

Burger, W. C. 1977. The Piperales and the monocots: alternative hypotheses for the origin of monocotyledonous flowers. Bot. Rev. 43:345-393.

Charlton, W. A., and U. Posluszny. 1991. Meristic variation in Potamogeton flowers. Bot. J. Linn. Soc. 106:265-293.

Cox, P. A., and R. B. Knox. 1989. Two-dimensional pollination in hydrophilous plants: convergent evolution in the genera Halodule (Cymodoceaceae), Halophila (Hydrocharitaceae), Ruppia (Ruppiaceae), and Lepilaena (Zannichelliaceae). Am. J. Bot. 76:164-175.

Cronquist, A. 1981. An integrated system of classification of flowering plants. Columbia University Press, New York.

Dahlgren, R., and F. N. Rasmussen. 1983. Monocotyledon evolution: characters and phylogenetic estimation. Evol. Biol. 16:255-395.

Endress, P. K. 1987. Floral phyllotaxis and floral evolution. Bot. Jahrb. Syst. 108:417-438.

Gamerro, J. C. 1968. Observaciones sobre la biologia floral 
y morfologia de la Potamogetonácea Ruppia cirrhosa (Petag.) Grande ( $=R$. spiralis L. ex Dum.). Darwiniana 14: 575-608.

Graves, A. H. 1908. The morphology of Ruppia maritima. Trans. Conn. Acad. Arts Sci. 14:59-170.

Jacobs, S. W. L., and M. A. Brock. 1982. A revision of the genus Ruppia (Potamogetonaceae) in Australia. Aquat. Bot. 14:325-337.

Kaul, R. B. 1992. Distribution, habitats, and taxonomy of Ruppia maritima $\mathrm{L}$. and $R$. occidentalis $\mathrm{S}$. Watson in $\mathrm{Ne}-$ braska. Trans. Nebr. Acad. Sci. 19:67-74.

Kubitzki, K. 1987. Origin and significance of trimerous flowers. Taxon 36:21-28.

Mason, R. 1967. The species of Ruppia in New Zealand. N. Z. J. Bot. 5:519-531.

Philbrick, C. T. 1988. Evolution of underwater outcrossing from aerial pollination systems: a hypothesis. Ann. Mo. Bot. Gard. 75:836-841.

Posluszny, U., and R. Sattler. 1973. Floral development of Potamogeton densus. Can. J. Bot. 51:647-656. 1974a. Floral development in Potamogeton richardsonii. Am. J. Bot. 61:209-216.

. 1974b. Floral development of Ruppia maritima var. maritima. Can. J. Bot. 52:1607-1612.

Roze, M. E. 1894. Recherches sur les Ruppia. Bull. Soc. Bot. France 41:466-481.

Singh, V. 1965. Morphological and anatomical studies in Helobiae. II. Vascular anatomy of the flower of Potamogetonaceae. Bot. Gaz. 126:137-144.

Tucker, S. C. 1989 . Overlapping organ initiation and common primordia in flowers of Pisum sativum (Leguminosae: Papilionoideae). Am. J. Bot. 76:714-729.

Van Vierssen, W., R. J. Van Wijk, and J. R. Van der Zee. 1982. On the pollination mechanism of some eurysaline Potamogetonaceae. Aquat. Bot. 14:339-347.

Verhoeven, J. T. A. 1979. The ecology of Ruppia-dominated communities in western Europe. I. Distribution of Ruppia representatives in relation to their autecology. Aquat. Bot. 6:197-268. 